\title{
The significance of air pollution in sugar maple decline
}

\author{
by Rachael L. Bell ${ }^{1}$, Andrea K. Graham ${ }^{1}$ and D.N. Roy ${ }^{2}$
}

Sugar maple decline has been a prominent issue since the late 1970s, when large areas of Quebec and Ontario were affected by this phenomenon. Links have been established between decline and insect damage, airborne heavy metals and acidic pollutants, and drought. Research has also indicated that global warming and resulting climactic changes may also cause decline. The phenomenon can be partially alleviated by proper management of sugar bushes. Although sugar maple decline has been on the wane over recent years, it may pose a serious problem in the future.

Key words: maple decline, pollution, acid rain, global warming, economy, prevention.
Le dépérissement de l'érable à sucre constitue une question préoccupante depuis la fin des années 1970, alors que de grandes superficies au Québec et en Ontario ont été affectées par ce phénomène. Des relations ont été établies entre le dépérissement et les attaques d'insectes, les métaux lourds contenus dans l'air et les polluants acides, et la sécheresse. La recherche a également démontré que le réchauffement et les modifications climatiques qui en résultent peuvent également engendrer le dépérissement. Le phénomène peut être partiellement atténué par un aménagement adéquat des érablières. Même si le dépérissement de l'érable à sucre a diminué au cours des dernières années, il pourrait occasionner de sérieux problèmes dans l'avenir.

Mots clés: dépérissement, pluies acides, réchauffement climatique, économie, prévention

\section{Introduction}

Eastern sugar maple (Acer saccharum) is an important and common part of the hardwood forests of Canada. Its valuable wood properties and use in producing maple syrup have been utilized over the centuries, and it is now valued throughout the world. This beautiful tree species is also internationally known for its vibrant colours in the autumn and bears special significance as a symbol of Canada.

The maple decline that occurred throughout the 1980 s, and the possibility of links between this phenomenon and air pollution, was the impetus for much research. How, and to what extent, air pollutants were damaging the forest became an important question that received widespread public attention, above and beyond concerns raised by foresters and scientists researching the issue. As a result the government received pressure to produce information on both topics. Although the phenomenon known as maple decline is still not clearly understood, some progress has been made. This paper will provide an overview of the current understanding of maple decline, in terms of science as well as policy.

\section{What is Forest Decline?}

Decline occurs over a large area of many square kilometers, and generally affects one particular tree species in any given outbreak (Smith 1991). Symptoms can be visible or invisible, rapid or progressive, chronic or acute. Usual symptoms include reduced growth, crown and twig dieback, abnormal leaf coloration, reduced leaf size, thinning and dying of leaves, and deterioration of roots (Backiel 1986).

Decline has always been a natural part of natural forest ecosystems (Smith 1991). Generally, this disease syndrome occurs when the trees are first weakened or altered by adverse environmental factors. These primary stress factors include drought or excessive rainfall, insect or disease infestations. These fac-

\footnotetext{
${ }^{1}$ Summer Research Assistants, Faculty of Forestry, University of Toronto. ${ }^{2}$ D.N. Roy, Professor, Faculty of Forestry, University of Toronto, 33 Willcocks St., Toronto, Ontario M5S 3B3.
}

tors can greatly weaken the health of the trees, leaving them susceptible to the invasion of secondary organisms, such as canker fungi, bark beetles and root and wood rots. Alone, these organisms are not a threat to the wellbeing of a healthy tree. But in an unhealthy environment, where there are many weakened trees, the results lead to the further weakening and possible mortality of large portions of the species population (Houston et al. 1990, McLaughlin et al. 1992).

Additional strains on the forest environment are caused by stresses resulting from air pollution. These usually weaken the trees, making them more susceptible to the damaging effects of the primary stress factors (McLaughlin et al. 1992).

\section{Maple Decline in Quebec and Ontario}

Much is still to be learned about the effects of air pollution on the forest, and how it contributes to forest decline. There is strong evidence, however, that air pollutants can have damaging effects upon the forest environment. This includes the obvious effects of pollution on the forest environmerts of Europe, as well as damaging results occurring much closer to home.

At the beginning of the last decade, several incidences of maple decline were reported in southern Quebec. This led to a series of surveys and inventories by the Quebec government to assess the degree and rate at which maple forests were being affected. In 1982, signs of decline were present in Beauce, Megantic, Frontenac and Arthabaska counties. Within two years, symptoms had spread east to Riviere-du-Loue, south to the Richelieu River, and north past the shores of the St. Lawrence River (Carrier 1986). This maple decline was the most severe and extensive decline occurring in recent history.

In analyzing the cause of this decline, foresters and scientists in Quebec considered a number of factors. Since the decline covered a large area and occurred over various ranges of ecological conditions, they believed that a widespread phenomenon must be involved. A comparative study was done on the ecological characteristics, background and management history of 195 sample plots in the area, to identify the primary and secondary causes of decline. After looking at the evidence, Carrier 
concluded that the effects of air pollution were the primary cause (Carrier 1986).

During this time, Ontario was also experiencing maple decline throughout the province. In 1978, the Ministry of the Environment investigated 8,100 ha in the Parry Sound area that showed symptoms of maple decline. By 1980, there were also occurrences of decline in Algonquin Park and Owen Sound (McLaughlin et al. 1992). Surveys were conducted to determine the extent of the decline throughout the province. Trees in the southwest and southeast of the province where the soil is deep, fine-textured and well buffered were considered to be in the healthiest conditions. The trees which were in the poorest condition were those growing on the shallow, poorly buffered soil of the Precambrian Shield. Generally, trees in northern Ontario were not as healthy as those in southern Ontario. However, the southwestern area of the province did have a higher frequency of declining trees. The general condition of the forest was visually quite healthy, and even in areas of high decline, serious regional mortality was not a problem (McIlveen and McLaughlin 1989). The health of the maple trees has generally improved since the mid-1980s (Hopkin and Dumond 1994).

Although maple decline in Ontario was not as extensive as that in Quebec, by 1984 the maple syrup producers of the province convinced the Ministry of the Environment that something must be done. A study was therefore initiated to determine the causal factors of decline in the province, and to assess the effects of air pollution on the forest and its contribution to the phenomenon. Permanent sample plots were established in woodlots located in the Muskoka, Peterborough and Thunder Bay areas. After seven years of measurements (1984 to 1990), the conclusion was that the primary factors for this outbreak of decline were climate stress and insect defoliation, i.e., tent caterpillars (McLaughlin et al. 1992). However, many other factors were involved making each individual incident of maple decline "a complex, multi-factorial, site specific phenomenon." The authors concluded that air pollution could not be ruled out as a stress factor that weakens the forest environment through its chronic presence. They also suggested that further research into the area of decline and air pollution may indicate that "tree decline across the province... is related to climate change through global warming." Should this prove to be true, then the stress from air pollution would be regarded not as the cause of, but rather a contributing factor towards, forest decline (McLaughlin et al. 1992).

In early January 1998, a severe ice storm passed through Southern Ontario and into the province of Quebec. At the time of writing, damage from this storm was still being surveyed, but it cannot be denied that the sugar maple population in this area was exceedingly hard hit, with many trees losing branches and in some cases their entire crown. The severe stress induced by this storm may be sufficient to spark a new incidence of decline across the affected area, if current theories regarding the link between climate change and decline prove to be correct.

\section{Links with Pollution}

In the recent Quebec maple decline situation, much of the available evidence seemed to suggest some involvement of air pollution. It has been difficult to link the exact relationship that air pollution has with the disease, due to the complex ways in which stress factors interact (Backiel 1986, McLaughlin et al.
1992). Nonetheless, air pollutants are not a natural source of stress, and the full impact of these pollutants on the forest has not yet been seen.

Air pollutants have the potential to cause adverse effects on the forest ecosystem through the accumulation of three major components: heavy metals, ozone, and acids. Even though acid deposition or "acid rain" may not be the most harmful of these three (Smith 1991), it has received the most attention from the media. Acid rain is the oxidation of sulphur dioxide and nitrogen oxide emissions in the atmosphere. The final products of the reactions are sulphuric and nitric acids, which are then deposited on the forest, either through precipitation or as dry matter (Smith 1991). It has been hypothesized that acid deposition may adversely affect forest health either by leaching nutrients from the soil more quickly than they can be replaced, or by increasing the biological availability of soil aluminum (Smith 1991).

On a local level, studies have shown that air pollutants can diminish forest growth (Backiel 1986). The regional effects are not as well documented. In general, air pollutants may injure trees through a direct or indirect pathway. The exposure of the tree crown to pollution may affect both the leaves (directly) and the stem (indirectly) of the tree (McLaughlin 1992). Direct pollution to the stem and surrounding soil must also be considered. The direct effects are usually seen within a single growing season (McLaughlin 1992), but the indirect impacts may not be seen for years, since the trees are usually affected by subtle chemical changes in the surrounding soil (Backiel 1986, McLaughlin 1992).

A recent study explored the relationship between sugar maple decline and corresponding changes in the stem tissue. Samples from maples in various stages of decline, from both acidic and calcareous sites, have shown that aluminum contents in the xylem reflect an increased availability of aluminum from acidic soils than from alkaline or neutral sites (Mohamed et al., 1996, communicated). Higher aluminum content may be one of the factors of decline. Another approach, to establish the physiological changes in declining and healthy maples from both acidic and calcareous sites, was to study the carbohydrate and trace elemental composition in early spring sap (Roy 1996). This study is still ongoing.

\section{Economic Losses}

Whether decline is the result of natural stresses or from manmade pollutants, maple decline does have negative effects on the economic aspects of the forests. For the maple syrup producers of Quebec, maple decline caused a 58\% drop in production of total maple products from $1981(13,458 \mathrm{kl})$ (Statistics Canada 1981) to 1982 (7,786 kl) (Statistics Canada 1982). Levels increased only slightly in the following years until 1988, when kilolitres of syrup produced were again at levels equal to those at the beginning of the decade (Statistics Canada 1988).

This drop in production suggests that air pollution may have an economic impact. Unfortunately, the many contributing stress factors that lead to decline interact in a wide variety of ways, making it very difficult to determine the exact economic impacts of individual factors. There are many different types of pollutants that may work individually or in combination, resulting in both short-term and long-term effects on the forest ecosystem. Currently, the exact ways in which air pollutants damage trees is not known, and therefore to determine 
the economic impacts would be a difficult task, however important it may be.

\section{Preventative Measures}

Since the phenomenon known as decline is so complex, involving both natural and artificial factors, at the current time control or cure for this disease is virtually impossible. However, there are both ecological and economic consequences of maple decline, and woodlot owners, especially those with sugarbush operations, are demanding information on how to reduce and possibly prevent the damaging effects of decline. Currently, government agencies are recommending proper management of the woodlots to reduce and eliminate many of the stress factors that could contribute to decline.

The remedial actions recommended by the Ontario Ministry of the Environment are based on sound principles of forest dynamics, silviculture and tree physiology (McLaughlin et al. 1992). One of the most important management techniques is the establishment of sugar bushes on sites which are best suited for maple, i.e., moderately deep, well drained, medium textured soils. It is also important to include other tree species that are naturally associated with the maple in management plans, as the presence of different species in the stand may reduce the impacts of insect infestation. Other recommendations include using proper thinning techniques for release of competition, and preventing excessive stand openings.

There are also additional considerations for stands used for maple syrup production, since tapping is an additional stress to the tree. Limiting the number of taps per tree and using clean equipment help to reduce stress. In years when the trees are exposed to other significant environmental stress, tapping operations should be halted (McLaughlin et al. 1992). Fertilization and liming have also shown success in reducing decline symptoms. This is based on the theory that air pollutants leach essential nutrients from the soil, and that fertilization may help to restore these nutrients. Liming is especially useful in controlling soil and water $\mathrm{pH}$. These treatments also increase tree vigour, which may increase the chances of individual trees surviving through harsh environmental stress (McLaughlin et al. 1992).

The above recommendations, while useful to woodlot owners concerned about the health of the sugar bush and wanting to prevent decline, do not solve the problem of maple decline. There is still much to be learned of the impacts of acid rain, and possible long-term effects that may effect the forest environment. Throughout the latter part of this century, governments around the world have begun to combat pollution. Emission standards have been set and emphasis has been placed on the discovery of low-waste technologies, and it is to be hoped that these trends will serve to reduce air pollution levels.

\section{Conclusion}

Much research still needs to be carried out on all aspects of maple decline, forest decline in general, and the impacts of air pollution on the forest environment. However, as the present condition of the maple forest seems to have improved since the mid-1980s, the demand for research in this area seems to be "on hold." This phenomenon may reoccur, however, and with the current variable climate it could be sooner than later. It may also happen on a much greater scale as the long term effects of air pollution further accumulate in the forest ecosystem.

The maple tree is an important part of Ontario and Quebec's natural heritage, ecologically, economically and aesthetically. If the most recent maple decline outbreak is just part of the hardwood forest's natural cycle, then the maple will continue to benefit those who utilize and admire the tree. However, if the overall health of the hardwood forest is being threatened by human activity, then the entire forest may be in danger from the damage that could result. The deterioration of the maple will have be of great economic detriment to maple syrup producers, threatening their livelihood. It may also lead to the loss of one of Canada's greatest and oldest traditions.

\section{References}

Backiel, A. 1986. Acid rain and forests - an attempt to clear the air. American Forests 92: 42-48.

Carrier, L. 1986. Decline in Quebec's forests - assessment of the situation. Service de la Recherché Appliqué, Direction de la recherché et du development, Sainte-Foy, Quebec.

Hopkin, A.A. and T. Dumond. 1994. Sugar maple health shows general improvement in Ontario. Frontline. Natural Resources Canada. Catalogue No. FO 29-29/17E, Ottawa, Ontario.

Houston, D.R., D.C. Allen and D. Lachance. 1990. Sugarbush Management: A guide to maintaining tree health. USDA Forest Service, Northeastern Forest Experiment, Radnor, PA.

Mcllveen, W.D. and D.L. McLaughlin. 1989. A survey to document the decline status of the sugar maple forest of Ontario: 1986. Air Resources Branch, Phytotoxicology Section. Ministry of the Environment, Toronto, Ontario.

McLaughlin D.L., D.E. Corrigan and W.D. McIlveen. 1992. Etiology of sugar maple decline at selected sites in Ontario (1984-1990). Air Resources Branch, Phytotoxicology Section. Report Number ARB-052.92-Phyto. Ministry of the Environment, Toronto, Ontario. Mohamed, H.K., S. Pathak, D.N. Roy, T.C. Hutchinson, D.L. McLaughlin and J.C. Kinch. 1996. Relationship between sugar maple decline and corresponding chemical changes in the stem tissue. J. Air Water Soil Pollution 96: 321-327.

Roy, D.N. 1996. Analysis of sap carbohydrate and trace elemental profile in healthy and declining maple trees. Private communication. Smith, W.H. 1991. Air pollution and forest damage. Chem. Eng. News 69(45): 30-43.

Statistics Canada. 1981. Catalogue No. 22-204.

Statistics Canada. 1982. Catalogue No. 22-204.

Statistics Canada. 1988. Catalogue No. 23-211. 